Research Article

\title{
Pengaruh Model Discovery Learning pada Materi Pencemaran Lingkungan terhadap Kemampuan Metakognitif Siswa Kelas $X$ SMA Negeri 3 Palangka Raya
}

\author{
Selvia Erianti ${ }^{\star *}$, Yula Miranda ${ }^{1}$, Akhmadi $^{1}$ \\ ${ }^{1}$ Program Studi Pendidikan Biologi, Fakultas Keguruan dan Ilmu Pendidikan, Universitas Palangka Raya, \\ Kota Palangka Raya, Indonesia \\ *emai: selviaerianti@gmail.com
}

Kata Kuci:

Discovery Learning

Hasil Belajar

Metakognitif

Pencemaran Lingkungan

Submitted: $29 / 08 / 2020$

Revised: 09/10/2020

Accepted: 01/12/2020

\begin{abstract}
Abstrak. Evaluasi pencapaian hasil belajar yang dilakukan oleh guru hanya berorientasi pada hasil belajar yang berkaitan dengan domain kognitif tanpa memperhatikan dimensi proses kognitif, khususnya kemampuan metakognitif. Kemampuan metakognitif merupakan salah satu faktor yang dapat mempengaruhi pencapaian hasil belajar. Hasil observasi di SMA Negeri 3 Palangka Raya menunjukkan bahwa 60\% siswa belum mencapai KKM yang ditetapkan oleh sekolah. Penelitian ini dilakukan dengan tujuan untuk: (1) mengetahui pengaruh model discovery learning terhadap kemampuan metakognitif siswa pada materi pencemaran lingkungan di kelas X SMA Negeri 3 Palangka Raya; dan (2) mengetahui pengaruh model discovery learning terhadap hasil belajar siswa pada materi pencemaran lingkungan di kelas X SMA Negeri 3 Palangka Raya. Penelitian ini merupakan pendekatan penelitian kuantitatif dengan jenis penelitian eksperimen semu (quasi experiment) menggunakan rancangan Pretest Posttest control group design yang melibatkan dua kelompok sampel yang dipilih menggunakan teknik purposive sampling, yakni kelompok eksperimen (kelas X-MIPA 1) dan kelompok kontrol (kelas X-MIPA 3). Data kemampuan metakognitif siswa dikumpulkan menggunakan instrumen angket Metacognitive Awareness Inventory (MAI) yang terdiri dari 30 pernyataan. Hasil analisis menunjukkan dari kemampuan metakognitif siswa bahwa thitung $(3,33)>$ tabel $(1,99)$ pada taraf signifikasi $5 \%$ maka Ha diterima dan Ho ditolak yang berarti model discovery learning berpengaruh signifikan terhadap kemampuan metakognitif siswa dengan kategori berkembang sangat baik dan hasil belajar siswa menunjukkan bahwa thitung $(2,51)>$ ttabel $(1,99)$ pada taraf signifikasi $5 \%$ maka Ha diterima dan Ho ditolak, yang berarti model discovery learning berpengaruh signifikan terhadap kemampuan metakognitif siswa pada materi pencemaran lingkungan kelas X SMA Negeri 3 Palangka Raya. Hal ini dapat dilihat dari nilai rata-rata posttest dan kemampuan metakognitif siswa pada kelompok eksperimen lebih tinggi dibandingkan dengan kelompok kontrol.
\end{abstract}




\section{PENDAHULUAN}

Pembelajaran biologi menekankan adanya kemampuan untuk berpikir kritis, logis, analitis, sistematis dan kemampuan memecahkan masalah serta menciptakan kreativitas dan bekerjasama atau berinteraksi dengan baik yang terbangun pada diri siswa. Seiring dengan perkembangan psikologi kognitif, maka berkembang pula cara guru dalam mengevaluasi pencapaian hasil belajar, guru umumnya hanya berorientasi pada hasil belajar yang berkaitan dengan domain kognitif dan kurang memperhatikan dimensi proses kognitif, khususnya pengetahuan metakognitif dan kemampuan metakognitif siswa. Peran guru dalam masalah ini juga bukan hanya berhubungan dengan isi mata pelajaran biologi saja, melainkan guru harus menempatkan dirinya dalam seluruh interaksinya dengan kebutuhan, kemampuan, dan kegiatan siswa. Penggunaan model pembelajaran yang sesuai akan membantu mempermudah guru untuk mencapai tujuan pembelajaran.

Model pembelajaran yang kurang efektif dan efisien, menyebabkan tidak seimbangnya kemampuan kognitif, afektif dan psikomotorik pada siswa, misalnya pembelajaran yang monoton dari waktu ke waktu yang dimaksud yaitu kebanyakan siswa menjadi lebih mudah mengingat ketimbang hanya membaca buku atau mendengarkan informasi dari guru, guru yang bersifat otoriter yaitu bimbingan yang diberikan kepada siswa berupa tugas semata, tanpa memperhatikan hubungan manusiawi antara guru dan siswanya sehingga sikap otoriter yang diterapkan seorang guru dalam mengelola pembelajaran sering kali membawa pengaruh yang kurang positif bagi para siswa dan kurang bersahabat dengan siswa, sehingga siswa merasa bosan dan kurang minat belajar. Arends (1997) berpendapat bahwa tidak ada model pembelajaran yang lebih baik dari model pembelajaran yang lain, karena masingmasing model mempunyai kelebihan dan kelemahan sendiri. Guru perlu menguasai dan dapat menerapkan berbagai model pembelajaran. Agar dapat mencapai tujuan pembelajaran yang sangat beranekaragam maka guru dapat memilih model pembelajaran yang cocok untuk mencapai tujuan pembelajaran tertentu atau yang sangat sesuai dengan lingkungan belajar atau sekelompok siswa tertentu. Tinggi rendahnya kadar keaktifan siswa dan prestasi belajarnya tergantung dari model pembelajaran yang digunakan.

Kemampuan metakognitif menurut Flavell dan Mc Cormick (dalam Slavin, 2008) diartikan sebagai pengetahuan tentang pembelajaran diri sendiri atau tentang bagaimana belajar. Siswa yang memiliki kemampuan metakognitif mampu mengontrol proses belajarnya, mulai dari tahap perencanaan, memilih strategi yang tepat sesuai masalah yang dihadapi, kemudian memonitor kemajuan dalam belajar, dan secara bersamaan mengkoreksi jika ada kesalahan yang terjadi selama memahami konsep, serta menganalisis keefektifan dari strategi yang dipilih (Iskandar, 2016).

Miranda (2010) menyatakan, bahwa hasil belajar siswa dapat dikatakan berkualitas apabila siswa secara sadar mampu mengontrol proses kognitifnya dan berdampak pada peningkatan kemampuan metakognitifnya. Keberhasilan pembelajaran dalam arti tercapainya standar kompetensi, sangat bergantung pada kemampuan guru mengolah pembelajaran yang dapat menciptakan 
situasi yang memungkinkan siswa belajar sehingga merupakan titik awal berhasilnya pembelajaran (Semiawan, 1985).

Berdasarkan hasil observasi kegiatan belajar mengajar dan wawancara dengan guru biologi kelas X SMA Negeri 3 Palangka Raya pada tanggal 18 Februari 2019, diketahui Kriteria Ketuntasan Minimal (KKM) mata pelajaran biologi di SMA Negeri 3 Palangka Raya kelas $X$ adalah 70 dengan KKM klasikal 72\%. Percapaian KKM klasikal masih rendah yaitu hanya $40 \%$ siswa yang tuntas, sehingga terdapat $60 \%$ siswa yang belum mencapai KKM yang ditetapkan oleh sekolah. Aktivitas belajar siswa umumnya masih rendah, Kebanyakan siswa masih belum mampu melakukan perencanaan diri dalam belajar, sehingga siswa tidak mengetahui apa tujuan yang ingin dicapai; siswa juga masih belum mampu memonitor diri sendiri seperti dalam merancang waktu yang tepat untuk belajar; siswa masih belum mampu mengevaluasi diri, membuat siswa kesulitan mengatasi masalah dalam belajar.

Hal ini disebabkan: (1) siswa selalu bergantung pada guru, (2) siswa tidak memiliki budaya belajar sendiri, (3) tanpa diterangkan guru siswa tidak mau belajar sendiri, (4) siswa cenderung kurang aktif dalam proses pembelajaran, (5) sebagian besar siswa belum mampu menghubungkan materi yang dipelajari dengan pengetahuan yang digunakan atau dimanfaatkan, (6) kemudian siswa kurang memperhatikan guru, (7) siswa masih beralasan saat mengerjakan tugas atau terlambat dalam mengumpulkan tugas dari guru terutama tugas rumah. Kemudian dari observasi yang dilakukan, seharusnya untuk meningkatkan kemampuan metakognitif siswa, guru dapat merancang pembelajaran berkaitan dengan kemampuan metakognitif, tetapi secara infuse/tambahan dalam pembelajaran atau bukan merupakan pembelajaran yang terpisah.

Hal tersebut menarik untuk diteliti dalam rangka mencari solusinya, serta untuk mengetahui apakah dengan menggunakan model pembelajaran yang sesuai dapat mempengaruhi keterampilan metakognitif siswa dan dapat meningkatkan hasil belajar siswa. Banyaknya teori dan hasil penelitian para ahli pendidikan yang menunjukkan bahwa pembelajaran akan berhasil bila siswa berpartisipasi aktif dalam proses pembelajaran. Model pembelajaran Discovery Learning penting dalam proses pembelajaran karena model pembelajaran yang menekankan pada pengalaman langsung dan pentingnya pemahaman struktur atau ide-ide penting terhadap suatu disiplin ilmu, melalui keterlibatan siswa secara aktif dalam pembelajaran.

Berdasarkan uraian di atas, maka penulis tertarik untuk melakukan penelitian dengan judul Pengaruh Model Discovery Learning pada Materi Pencemaran Lingkungan terhadap Kemampuan Metakognitif dan Hasil Belajar Siswa Kelas X SMA Negeri 3 Palangka Raya.

\section{METODE}

Pendekatan yang digunakan pada penelitian ini adalah pendekatan deskriptif kuantitatif. Jenis penelitian dalam penelitian ini termasuk jenis penelitian eksperimen semu (quasi experiment) yang dilaksanakan pada dua kelas, yaitu pada kelas eksperimen dan kelas kontrol.

Tabel 1. Desain Penelitian

\begin{tabular}{llll}
\hline Kelompok & Pretest & $\begin{array}{l}\text { Variabel } \\
\text { Bebas }\end{array}$ & Posttest \\
\hline Eksperimen & O1 & X1 & O2 \\
Kontrol & O2 & X2 & O4 \\
\hline
\end{tabular}


Keterangan:

$\mathrm{X} 1=$ Pemberian perlakuan (menggunakan model discovery learning)

X2 = Pemberian perlakuan (menggunakan model konvensional)

$\mathrm{O} 1=$ Tes awal atau pretest kelas eksperimen

$\mathrm{O} 2$ = Tes akhir atau posttest kelas eksperimen

O3 = Tes awal atau pretest kelas kontrol

$\mathrm{O} 4$ = tes akhir atau posttest kelas control

Penelitian ini dilakukan di SMA Negeri 3 Palangka Raya yang berada di Jalan George Obos No.12 Palangka Raya pada tahun ajaran 2018/2019. Waktu penelitian ini direncanakan secara efektif dimulai bulan April dan berakhir pada bulan Juni 2019. Instrumen yang digunakan dalam penelitian ini adalah dengan rencana pelaksanaan pembelajaran (RPP) dan lembar kerja peserta didik (LKPD). Memberikan soal pretest dan posttest pilihan ganda sebanyak 40 butir soal, pengukuran kemampuan metakognitif atau Metacognitive Achievement Inventory (MAI) berisikan angket 30 pernyataan positif dengan tiap-tiap pernyataan diikuti 2 pilihan "Ya" atau "Tidak" jawaban yang menunjukkan frekuensi keterlaksanakan kegiatan., Pemberian soal pretest dan posttest yang dilakukan pada awal dan akhir kegiatan pembelajaran untuk memperoleh data hasil belajar yang dimiliki siswa kelas eksperimen dan kontrol dari kegiatan pembelajaran sebelum dan setelah menggunakan model pembelajaran Discovery Learning. Teknik pengumpulan data pada hasil belajar peserta didik ranah kognitif yaitu dengan teknik tes menggunakan soal tes berupa pretest dan posttest. Skor soal tes adalah 5 untuk jawaban benar dan 0 untuk jawaban salah.
Data yang diperoleh dilakukan yaitu meliputi uji normalitas dan uji homogenitas, terhadap nilai pretest dan posttest kedua kelas. Uji normalitas ini bertujuan untuk mengetahui apakah varian dapat berdistribusi normal atau tidak. Uji normalitas ini menggunakan rumus Chi Square, yaitu untuk mengetahui distribusi data yang diperoleh dari nilai tes masingmasing kelompok siswa tersebut. Uji homogenitas ini bertujuan untuk mengetahui apakah varian bersifat homogen atau tidak, untuk uji homogenitas digunakan rumus Fisher.

Mengukur kemampuan metakognitif menggunakan lembar invektori kemampuan metakognitif atau Metacognitive Achievement Inventory (MAl) yang diadaptasi dari Assesing Metacognitive Awarness oleh Schraw, G., dan Dennison, $\mathrm{R}, \mathrm{S}$ (1994), terdiri atas

30 pernyataan positif dengan tiap-tiap pernyataan diikuti dengan 2 pilihan jawaban yaitu "Ya" atau "Tidak" yang menunjukkan frekuensi keterlaksanaan kegiatan.

Sebelum melakukan uji-t diperlukan uji homogenitas, jika data bersifat homogen maka data hasil penelitian yang terkumpul akan diuji dengan melakukan uji-t. Data hasil penelitian dianalisis secara kuantitatif sebelum membuat kesimpulan. Data yang telah terkumpul diuji agar hasil analisis yang diperoleh lebih ilmiah dengan melakukan uji-t.

\section{HASIL DAN PEMBAHASAN}

\subsection{Hasil Penelitian}

Deskripsi data pengamatan dalam penelitian ini berupa data kemampuan metakognitif siswa yang dibelajarkan melalui model Discovery Learning pada materi pencemaran Lingkungan. Kemampuan metakognitif di ukur menggunakan angket Metacognitive 
Awareness Inventory (MAI) yang meliputi tiga indikator metakognitif, yakni planning, monitoring dan evaluating. Data lengkap kemampuan metakognitif kelas eksperimen dan kelas kontrol secara umum disajikan pada tabel 2.

Tabel 2. Rata-rata nilai kemampuan Metakognitif Tiap Indikator Kelompok Eksperimen dan Kontrol

\begin{tabular}{ccc}
\hline \multirow{2}{*}{ Indikator Metakognitif } & \multicolumn{2}{c}{ Nilai Rata-rata } \\
\cline { 2 - 3 } & Eksperimen & Kontrol \\
\hline Planning & 82,29 & 76,00 \\
Monitoring & 83,71 & 69,43 \\
Evaluating & 76,86 & 70,00 \\
\hline
\end{tabular}

Data pada tabel 2 menunjukkan ratarata nilai kemampuan metakognitif tiap indikator pada kelompok eksperimen dan kontrol yang mempresentasikan tiga indikator metakognitif yakni planning, monitoring, dan evaluating. Data perbandingan nilai rata-rata kemampuan metakognitif tiap indikator antara kelompok eksperimen dan kelompok kontrol. Diagram rata-rata nilai kemampuan metakognitif tiap indikator pada kedua kelas disajikan seperti gambar 1.

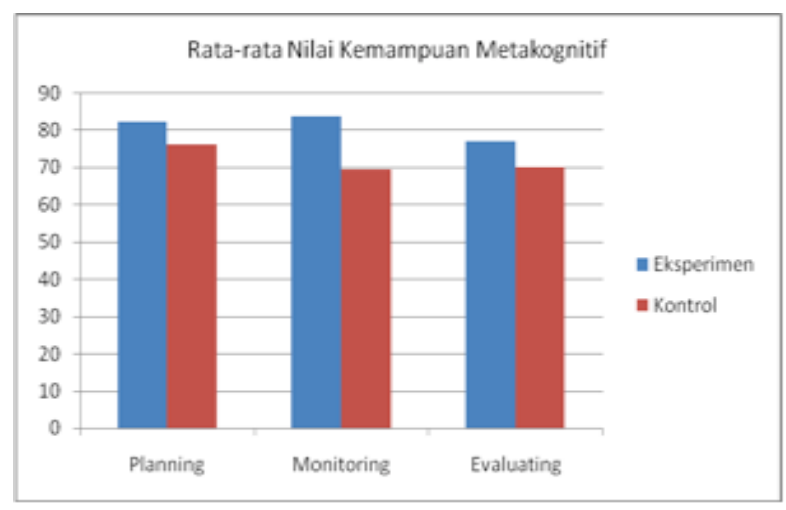

Gambar 1. Diagram Perbandingan Nilai Rata-rata Kemampuan Metakognitif Tiap Indikator antara Kelompok Eksperimen dan Kelompok Kontrol
Indikator yang di ukur pada gambar 7 meliputi planning, monitoring dan evaluating. Hasil penelitian pada gambar 7 memperlihatkan pada kelompok eksperimen, indikator planning termasuk kedalam kategori berkembang sangat baik, sedangkan indikator monitoring dan evaluating termasuk kedalam kategori berkembang dengan baik. Kemudian untuk kelompok kontrol, indikator planning, monitoring dan evaluating termasuk dalam kategori mulai berkembang. Jadi, kemampuan metakognitif yang dibelajarkan dengan model Discovery Learning lebih baik dibanding dengan kemampuan metakognitif yang dibelajarkan melalui pembelajaran konvensional.

Indikator yang di ukur pada gambar 2 meliputi planning, monitoring dan evaluating. Hasil penelitian pada gambar 2 memperlihatkan pada kelompok eksperimen, indikator planning termasuk kedalam kategori berkembang sangat baik, sedangkan indikator monitoring dan evaluating termasuk kedalam kategori berkembang dengan baik. Kemudian untuk kelompok kontrol, indikator planning, monitoring dan evaluating termasuk dalam 
kategori mulai berkembang. Jadi, kemampuan metakognitif yang dibelajarkan dengan model Discovery Learning lebih baik dibanding dengan kemampuan metakognitif yang dibelajarkan melalui pembelajaran konvensional.

Tabel 3. Data Nilai rata-rata Kemampuan Metakognitif Kelompok Eksperimen dan Kontrol

\begin{tabular}{lcccccc}
\hline Kelompok & N & Rata-rata & $\begin{array}{c}\text { Nilai } \\
\text { Tertinggi }\end{array}$ & $\begin{array}{c}\text { Nilai } \\
\text { Terendah }\end{array}$ & $\begin{array}{c}\text { Standar } \\
\text { Deviasi }\end{array}$ & Varians \\
\hline Eksperimen & 35 & 80,95 & 100,00 & 46,67 & 11,56 & 133,71 \\
Kontrol & 35 & 71,81 & 86,67 & 40,00 & 11,41 & 130,29 \\
\hline
\end{tabular}

Data pada tabel 3 menunjukkan bahwa kemampuan metakognitif kelompok eksperimen memiliki nilai rata-rata 80,95 yang berada pada kriteria berkembang sangat baik dengan standar deviasi 11,56. Kemudian, kemampuan metakognitif kelompok kontrol memiliki ratarata 71,81 yang berada pada kategori mulai berkembang dengan standar deviasi 11,41.

Deskripsi data pengamatan dalam penelitian ini berupa hasil belajar pada ranah kognitif diukur menggunakan tes pilihan ganda sebanyak 40 butir soal. Kegiatan tes ini diikuti oleh 35 siswa untuk kelas eksperimen dan 35 kelas kontrol. Tes ini dilakukan pada awal pembelajaran (pretest) dan akhir pembelajaran (posttest). Tes ini dilakukan untuk mengetahui pengaruh antara model pembelajaran Discovery Learning dengan model pembelajaran konvensional. Data lengkap (pretest) dan (posttest) kelas eksperimen dan kelas kontrol secara umum disajikan pada tabel 4 .

Tabel 4. Hasil Belajar Kognitif Pretest dan Posttest Kelas Eksperimen dan Kelas Kontrol

\begin{tabular}{lcccc}
\hline \multirow{2}{*}{ Komponen } & \multicolumn{2}{c}{ Pretest } & \multicolumn{2}{c}{ Posttest } \\
\cline { 2 - 5 } & Eksperimen & Kontrol & Eksperimen & Kontrol \\
\hline Jumlah Siswa & 35 & 35 & 35 & 35 \\
Skor Terendah & 25,00 & 10,00 & 42,50 & 27,50 \\
Skor Tertinggi & 75,00 & 70,00 & 90,00 & 87,50 \\
Rata-rata & 51,87 & 36,50 & 76,43 & 65,93 \\
\hline
\end{tabular}

Data pada tabel 4 menunjukkan data hasil pretest kelas eksperimen (Kelas $\mathrm{X}$ MIPA 1) memiliki nilai terendah 25,00 dan nilai tertinggi 75,00 dengan rata-rata sebesar 51,87. Data pretest kontrol (Kelas $X$ MIPA 3) memiliki nilai terendah sebesar 10,00 dan nilai tertinggi 70,0 dengan ratarata sebesar 36,50. Hasil posttest kelas eksperimen menunjukkan nilai terendah
42,50 dan nilai tertinggi 90,00 dengan ratarata sebesar 76,43 sedangkan pada kelas kontrol memiliki nilai terendah 27,50 dan nilai tertinggi 87,50 dengan nilai rataratanya sebesar 65,93 .

\subsection{Pembahasan}

Perbandingan nilai rata-rata tiap indikator kemampuan metakognitif planning 
sebesar (82,29), Monitoring sebesar $(83,71)$, dan Evaluating sebesar $(76,86)$ pada kelompok eksperimen sedangkan nilai rata-rata tiap indikator pada kelompok kontrol planning sebesar $(76,00)$, monitoring sebesar $(69,43)$, dan Evaluating sebesar $(70,00)$, dengan nilai rata-rata kelompok eksperimen kemampuan metakognitif yaitu $(80,95)$ dengan kategori berkembang sangat baik sedangkan nilai kemampuan metakognitif kelompok kontrol 71,81 dengan kategori mulai berkembang. Hasil ini menunjukkan bahwa model pembelajaran melalui Discovery Learning siswa dapat menemukan konsep tersebut secara mandiri dan memperkuat konsep biologi karena memperoleh kepercayaan siswa untuk bekerja sama dengan yang lainnya, sehingga menguatkan ingatan siswa dan melatih kemampuan metakognitif. Pengaruh model pembelajaran khususnya model Discovery Learning terhadap kemampuan metakognitif siswa kelas eksperimen terjadi karena dalam proses belajar mengajar, siswa menjadi lebih aktif dan terlibat langsung untuk mendapatkan pengetahuan yang lebih.

Berdasarkan analisis hasil belajar kognitif siswa diperoleh nilai rata-rata pretest kelas eksperimen sebesar 51,87 dan kelas kontrol sebesar 36,50. Hasil analisis data menunjukkan bahwa nilai ratarata pretest eksperimen dan pretest kontrol memiliki nilai rata-rata yang rendah, hal ini menunjukkan bahwa kedua kelas yang diberi perlakuan memiliki kemampuan awal yang sama. Rendahnya perolehan nilai rata-rata pretest ini disebabkan materi yang diujikan belum diajarkan sebelumnya oleh siswa, sehingga siswa menjawab pertanyaan sesuai dengan pengetahuan mereka masing-masing.

Analisis nilai rata-rata hasil belajar kognitif siswa, diperoleh hasil posttest kelompok eksperimen yaitu 76,43 dan hasil posttest kelompok kontrol 65,93. Hasil belajar kognitif siswa kelas eksperimen dan kelas kontrol dianalisis menggunakan uji-t untuk menguji hipotesis nilai posttest, diperoleh thitung $(2,51)>$ ttabel $(1,99)$. Dari hasil tes kemampuan awal dan tes kemampuan akhir diketahui bahwa hasil belajar kognitif siswa kelas eksperimen mengalami peningkatan dengan penerapan model Discovery Learning. Nilai rata-rata siswa kelas eksperimen setelah penerapan Model Discovery Learning lebih tinggi dibandingkan nilai rata-rata siswa sebelum penerapan Model Discovery Learning. Siswa yang dibelajarkan dengan model pembelajaran Discovery Learning memperoleh nilai rata-rata hasil belajar yang sangat tinggi dibandingkan dengan siswa yang dibelajarkan menggunakan model pembelajaran konvensional. Kemudian dari hasil posttest kelompok eksperimen menunjukkan bahwa $86 \%$ siswa sudah mencapai ketuntasan yang ditetapkan oleh sekolah, sedangkan dari hasil posttest kelompok kontrol menunjukkan hanya beberapa siswa saja yang sudah mencapai ketuntasan yang ditetapkan oleh sekolah, sehingga harus ditingkatkan lagi. Hal ini karena siswa yang dibelajarkan dengan menggunakan model Discovery Learning dilibatkan langsung dalam proses pembelajaran dengan sumber belajar yang nyata di dalam kelas sehingga merangsang untuk melatih kemampuan siswa dan memudahkan siswa dalam menguasai konsep-konsep yang dipelajari guna memecahkan masalah dunia nyata, kemudian mampu mengembangkan kemampuan siswa untuk berpikir kritis.

\section{KESIMPULAN}

Model Discovery Learning berpengaruh terhadap kemampuan metakognitif dan 
hasil belajar siswa pada materi Pencemaran Lingkungan di kelas X SMA Negeri 3 Palangka Raya. Hal ini ditunjukkan dari hasil kemampuan metakognitif siswa bahwa thitung $(3,33)$ lebih besar ttabel $(1,99)$ pada taraf signifikansi 5\% maka Ha diterima dan $\mathrm{HO}$ ditolak dengan kategori berkembang sangat baik. Kemudian dari hasil analisis terhadap kemampuan metakognitif bahwa nilai thitung $(2,51)>$ ttabel $(1,99)$ pada taraf signifikansi $5 \%$ maka $\mathrm{Ha}$ diterima dan $\mathrm{Ho}$ ditolak dengan kategori sangat tinggi.

\section{Referensi}

Anas, Sudijono. 2011. Pengantar Evaluasi Pendidikan. Jakarta : Raja Grafindo Persada.

Arifianti, Hilda. 2013. Meningkatkan Hasil Belajar Ipa Melalui Penerapan Model Quantum Teaching Di Kelas V Sd Negeri Bhakti Karya Depok. Skripsi. Yogyakarta : Universitas Negeri Yogyakarta.

Coebima, A, D. 2006. Metakognisi : Suatu Ringkasan Kajian. Makalah Disajikan Dalam Pelatihan Strategi Metakognitif Pada Pembelajaran Biologi Untuk Guru-Guru Biologi Sma Lembaga Pengabdian Kepada Masyarakat (Lpkm) Unpar. Palangka Raya : UPR

Daniel, Muhammad. 2010. Pengaruh Strategi Discovery Learning Terhadap Keterampilan Metakognitif Dan Respon Mahasiswa. Jurusan Kimia Fmipa Unm. Jurnal Chemica Vol. 11 Nomor 2 Desember 2010, Hal. 1-10.

Flavell., \& Cindy. 1979. Metacognition And Cognitive Monitoring : A New Area Of Cognitive - Developmental Inquiry. American Psychological Association, Inc . Diunduh Pada Tanggal 23 Maret
2019,

Dari http://www/scribd.com//doc//45848755 //flavell-1979metacognition-andcognitive-monitoring.

Fauziah, Anna. 2010. Peningkatan Kemampuan Pemahaman Dan Pemecahan Masalah Matematika Siswa Smp Melalui Strategi React. Forum Kependidikan, 30(1), 1-13.

Galyam, N., \& Le Grange, L. 2005. Improving Thinking Skill In Science Of Learners With (Dis)Abilities. South African Journal Of Education, 25(4), HIm.239-246.

Hadi, S. 2007. Pengaruh Pembelajaran Kooperatif Script Terhadap Keterampilan Berpikir Kritis, Metakognitif Dan Hasil Belajar Biologi. Malang : UMM.

Kusumaningtias, Anyta., Siti Zubaidah., \& Sri Endah Indriwati.(April 2013). Pengaruh Problem Based Learning Dipadu Strategi Numbered Heads Together Terhadap Kemampuan Metakognitif , Berpikir Kritis, Dan Kognitif Biologi. Jurnal Penelian Kependidikan Tahun 23 Nomor 1.

Nana, Sudjana.2009. Penilaian Hasil Proses Mengajar. Bandung : Remaja Rosdakarya.

Mahendra., Dkk. 2014. Pengaruh Model Pembelajaran Bevbasis Masalah Terhadap Hasil Belajar Ipa Siswa Kelas V Sd.. Diunduh Pada Tanggal 1 April 2019, Dari http://ejournal.undiksha.ac.id/indek.ph p.

Masrura, Siti, Inayah. 2013. Faktor-Faktor Psikologis Yang Mempengaruhi Kesadaran Metakognisi dan Kaitannya dengan Prestasi Belajar 
Matematika. Makassar. Jurnal Matematika dan Pembelajaran (MAPAN), Vol.1 No.1 Desember 2013:1-18.

Maulana. 2008. Pendekatan Metakognitif Sebagai Alternatif Pembelajaran Matematika Untuk Meningkatkan Kemampuan Berpiki Kritis Mahasiswa PGSD. Jurnal Pendidikan, No.10.

Miranda, Yula. 2010. Pembelajaran Metakognitif Dalam Strategi Kooperatif Think-Pair-Share dan Think-Pair-Share Metakognitif Terhadap Kemampuan Metakognitif Siswa Pada Biologi Di SMA Negeri Palangka Raya. Skripsi. Palangka Raya : Universitas Palangka Raya. 